\title{
NATIVE RIGHTS IN THE NORTHWEST TERRITORIES - THE CAVEAT CASE
}

The question of the validity of aboriginal rights in the native people of the Northwest Territories has received increasing attention over the past year. Although this area of law is at present poorly defined, its importance is becoming increasingly apparent. Effective recognition of such rights would inevitably lead to reform in the handling of native affairs throughout Canada. Recent court cases, coupled with an apparent mellowing in the attitudes of the federal government have encouraged the possibility of such recognition. The latest development in the courts, a reference ${ }^{2}$ under the Land Titles Act, ${ }^{2}$ heard by Mr. Justice Morrow in the Territorial Court of the Northwest Territories, affords the opportunity of a real turning point, from both legal and strategic standpoints, in the quest for recognition.

The case is concerned with a reference to the court under s. 154(1)(b) of the Land Titles Act in regard to the attempted filing of a caveat by sixteen chiefs of Indian communities in the north. The caveat purported to protect any existing aboriginal title in unpatented Crown land historically used by the natives and coming within the terms of Treaties $8^{3}$ and $11 . .^{4}$ This land includes the greater part of the Mackenzie District of the Northwest Territories and, in particular, the Mackenzie Valley. The intended effect of the caveat was to halt extinction of native title by making any future registrations in relation to the land concerned expressly subject to existing rights.

Generally, the Indians have achieved a twofold purpose through their use of the mechanics of the Land Titles Act: First, from a strategic point of view they have succeeded in directly involving parties other than the natives themselves in the dispute. Immediately after the matter was referred to Mr. Justice Morrow, he instituted a type of "land freeze" until he could deliver his decision. The registrar was restrained from registering or filing any instrument in respect to the land in question during the adjournment unless the party presenting the instrument executed a covenant consenting to and preserving whatever priority the caveat may have over that instrument. After the decision was handed down, the caveat was not filed ${ }^{5}$ but, rather, the Registrar was required to keep a record of all transactions registered or recorded in his office until after the appeal proceedings $^{\circ}$ from the decision were exhausted. The dispute is no longer one of hypothetical allegations between the natives and the federal government. The Indians have succeeded in posing a threat to the status quo of development methods in the North. The possibility of a caveat being filed, with resultant effects on the rights of third parties, could serve to bring about a careful consideration and favourable settlement of aboriginal claims. Secondly, Mr. Justice Morrow held that the Indians had a prima facie interest in the land capable of being the subject of a caveat. Therefore, in any future action on notice to lapse this caveat, if filed, the stage will be set for several ambiguous areas in the law of aboriginal rights to be more fully explored by the courts.

${ }^{1}$ Re Paulette's Application to file a Caveat [1973] 6 W.W.R. 97 (N.W.T.S.C.).

2 R.S.C. 1970 , c. L-4.

${ }^{3}$ June 21, 1899, P.C. No. 2749.

- June 27, 1922. Queen's Printer, Ottawa, 1967. Cat. No. R33-1167 (reprinted).

5 This action was ordered to protect the caveators against possible damages which could arise if the caveat was filed and then subsequently not sustained on a notice to lapse the caveat. Mr. Justice Morrow found it to be within his discretion to make such an order.

- At the time of writing, an appeal has been launched by the Crown. 


\section{HISTORY OF THE DISPUTE}

The Athapascan tribes of the Mackenzie Basin were brought under treaty by the federal government through Treaties 8 , in 1889 , and 11 , in 1921 . These Treaties purportedly cover an area bounded by the 60th parallel in the south, the Yukon border in the west, the Arctic Ocean on the north and, in the east by a line running from Coppermine through Lake Contwoyto to Fond du Lac at the eastern end of Lake Athabasca. ${ }^{7}$

The dispute arising under these Treaties concerns a promised land settlement of one square mile per family of five which has never been fulfilled. ${ }^{8}$ During the forty five years following the signing of Treaty 11, there has been no evidence of a pressing desire from either side to effect this settlement. In 1950, the Territorial Lands Act ${ }^{9}$ was amended to enable the fulfillment of this obligation under fairly wide terms but was not acted upon. In 1959, the Committee of the Privy Council recommended effective action on settlement due to the increasing development in the region. A commission was established which held meetings with the Indians but, again, no effective settlement was reached. Only in the last several years, in the face of rapid development in the North, have serious efforts at settlement taken place.

However, the last several years have seen the expectations of the form of settlement desired by the natives change considerably. The Indian Affairs Department has expressed an ever-increasing desire to negotiate an immediate settlement of the outstanding claims on a basis of actual delivery of the land or a cash substitute basis. ${ }^{10}$ They have not been received enthusiastically. The native organizations in the North claim they will only approach a bargaining table from a position of equality in the sense of adequate knowledge and research of their legal position. They do not want a premature settlement forced on them in the face of such possible developments as the Mackenzie Valley pipeline. ${ }^{11}$ The Alaska Settlement of 1972, which conferred a combined cash, land and participating royalty settlement on the Alaskan natives, has surely affected native expectations and their object in any settlement will certainly include a share in future development of the North. This is not possible under the set provisions of the present treaties and would involve a complete renegotiation of them. Government policy has refused to consider this possibility in the past.

In the past year, developments in the courts have provided an excellent lever to be used by the natives in attaining their goals. The case of Calder et al. v. A.G. B.C.12 in the Supreme Court of Canada affirmed the existence of aboriginal rights at common law, independent of express statutory recognition and left open the possibility of legal settlement in situations where government policy had not effectively settled native claims. This was directly opposed to the announced federal government position in the White Paper on Indian Affairs in 1969. In reference to grievances based on aboriginal title the report stated:13

It should be noted that, in their caveat, the Indians have made no claim to the oil rich Mackenzie Delta on the Arctic coast since this territory was traditionally Eskimo and never used by the Indians. The Eskimo people were not signatories to the treatis, and, even though Treaty 11 purports to cover this area, it could be argued that it does not do so since under its terms only "Indian Territory" was ceded.

8 The total area of land involved would now be approximately 600,000 acres.

S.C. 14 Geo. VI, c. 22 , s. 18 (d).

10 See e.g., the department communique, June 28, 1972.

11 Edmonton Journal, May 19, 1972.

12 [1973] 4 W.W.R. 1, 34 D.L.R. (3d) 145 (S.C.C.).

13 Queen's Printer, Ottawa, 1969. Cat. No. R32-2469 at 11. 
These are so general and undefined that it is not realistic to think of them as specific claims capable of remedy except through (government policy) that will end injustice to Indians....

The natives now appear to have an alternative solution to turn to rather than reliance on "one-sided" negotiation with the government. The government cannot ignore these developments in the courts when formulating their future policies. Whether used alone, or as leverage in negotiations, this increasingly successful access to the courts has certainly served to narrow the credibility gap in native assertions. Against this current context of developments, the Caveat case could well serve the function of redefining the legal issues and political positions of the parties involved.

\section{THE LEGAL BACKGROUND ${ }^{14}$}

The concept of aboriginal title constitutes a poorly defined area of the Canadian legal system. British policy, when dealing with Indian lands, recognized certain rights in the native people and this recognition was periodically embodied in legislative enactments. However, the effect of this recognition has never been properly weighed by either the courts or the federal government. To properly assess the status of the Caveat case in the context of the developing law in this area, it is necessary to consider the various interpretations of the concept available. A framework can then be established through which possible settlement of the issue in the Northwest Territories can be discussed.

\section{Existence of Aboriginal Rights}

Aboriginal rights can be defined generally as "those property rights which inure to native people by virtue of their occupation upon certain lands from time immemorial." Historically, these rights were the basis on which land dealings with the natives were undertaken. In situations where such rights have not already been ceded, for example, by treaties, the natives argue that negotiations should not be based on arbitrary government policy but rather on a bargaining process whereby they continue to possess certain rights to the land.

In general, the courts have insisted that native claimants satisfy certain requirements of possession and occupation before an aboriginal claim will be recognized..$^{15}$ Various factors taken into consideration include degree of attachment to the land, length of time occupied, exclusive control of a "defined" territory and consideration of these factors in the context of the legal concepts of the people in question. ${ }^{16}$ Once these requirements are met, the courts will look for a recognition of the right in the jurisdiction in question.

\section{Recognition in the Northwest Territories}

The leading Canadian document on native rights is the Royal Proclamation of $1763,{ }^{17}$ incorporated into the Treaty of Paris, which forbade settlement upon Indian lands and directed that such lands be obtained only by cession or

14 This discussion follows the framework for analysis of aboriginal title used by Cumming and Mickenberg, Native Rights in Canada (2d ed. 1972).

15 It should be noted that many of the cases relied upon in this area are American. This reliance is based on the fact that the origins of the American aboriginal rights doctrine are prior to the Revolution and are based on British policy and law. Thus, the principles relied upon are similar to those which have also continued to be recognized and applied in Canada. As is evidenced in the Calder case, supra, n. 12, American case law is thus given significant weight in Canadian courts.

${ }^{16}$ Supra, n. 14 at 48-50. Cases cited include: In re Southern Rhodesia [1919] A.C. 211 (P.C.); United States v. Seminole Indians (1967) $180 \mathrm{Ct}$. Cl. 375 at 383; Confederated Tribes v. United States (1966) Ct. Cl. 184 at 194; Spokane Tribe of Indians v. United States (1963) Ct. Cl. 58.

17 Reprinted in R.S.C. 1970, Appendices at 127-129. 
purchase. ${ }^{18}$ Therefore, the Indians were recognized as having certain rights in the land which they could not be deprived of arbitrarily. The Proclamation is regarded as the basis on which principles of negotiating cession of land from the natives were formulated. However, the geographical area covered by the Proclamation has not been legally settled. It is possible to argue that the Northwest Territories are beyond its scope by virtue of the territory being terra incognita at the time of the passing of the Proclamation. It should also be noted that the intent of the Proclamation could be viewed as a reward to the Indian people who aided the British during the Seven Years War, thus removing the natives of the North from its contemplation.

There are, however, several other legislative enactments applicable to the Northwest Territories which do give recognition to aboriginal rights. The Hudson Bay Company passed several ordinances and entered into treaties with the natives they came into contact with which implied that they recognized aboriginal titles as a fetter upon their own title. The Order in Council of $1870^{19}$ transferring Rupert's Land to Canada under s. 146 of the B.N.A. Act and Rupert's Land Act ${ }^{20}$ of 1868 provided that any existing Indian claims of compensation would be disposed of by the Canadian government. This recognition of aboriginal title in Rupert's Land takes on added significance when it is noted that this territory was specifically exempted from the Proclamation and is thus evidence that Imperial policy was to recognize title outside the Proclamation. The same order in council transferred the Northwest Territories to Canada and, thus, this transfer was made subject to the same condition under the same policy considerations. ${ }^{21}$ Also, Treaties 8 and 11 appear to have been based on the recognition of aboriginal rights. For example, Treaty 8 stipulated that the Indians yielded "all their rights, titles and privileges whatsoever to the lands included". ${ }^{22}$ If there was no title, why were the treaties negotiated? Further evidence of legislative recognition may be found in provisions of early Dominion Lands Acts confirming aboriginal title. ${ }^{23}$

Aside from legislative recognition, consideration has also been given to the fact that the right has been recognized by implication in historical dealings with the Indians. In $R$. v. Sikyea, Mr. Justice Johnson noted that it was doubtful the Proclamation applied to the N.W.T. but added: ${ }^{24}$

The fact is not important because the government of Canada has treated all Indians . . . as having an interest in the lands that required a treaty to effect its surrender.

Thus, there appears to be ample authority to support the recognition of aboriginal title in the natives of the Northwest Territories. However, evidence of recognition by itself cannot support an effective remedy in a claim asserting this title. There must also be a legal obligation on the Crown to make adequate compensation for cession of such rights. As outlined in the next section, the courts are undecided as to the nature of this obligation. There is also no authoritative test by which the courts determine whether title still exists or whether it has been extinguished by previous government policy and legislation.

18 The Proclamation was an executive order having the force of a law of Parliament and, as such, having never been repealed, is embodied in the law of Canada by the Colonial Laws Validity Act.

19 Reprinted in R.S.C. 1970, Appendices at 257-63.

20 (Imp.) 31 and 32 Vict., c. 105.

21 Cumming and Mickenberg, supra, n. 14 at 149.

22 Supra, n. 3.

${ }^{23}$ E.g., the 1879 Act, 42 Vict., c. 31, s. 125 (e), gave the Governor in Council power "to satisfy any claims existing in connection with the extinguishment of the Indian title".

24 (1964) 43 D.L.R. (2d) 150 at 152. (N.W.T.C.A.). 


\section{Content of Aboriginal Rights}

The basis of the content of aboriginal title is contained in several American decisions by Chief Justice Marshall in the early nineteenth century. ${ }^{25}$ It has been pointed out that the rules laid down have their roots in the international law doctrine that discovery confers ultimate title on the discoverer and that conquered people come within the allegiance of the King. Native title thus became subordinate to the rights of the Crown but was accorded recognition in consideration of the natives' newly acquired status as British subjects. ${ }^{26}$ Marshall C.J. states the effect of the coming of the Europeans to North America on the rights of the Indians: ${ }^{27}$

They were admitted to be the rightful occupants of the soil, with a legal as well as a just claim to retain possession of it, and to use it according to their own discretion; but their right to complete sovereignty, as independent nations was necessarily diminished and their power to dispose of the soil at their own will, to whomsoever they pleased, was denied by the original fundamental principle that discovery gave exclusive title to those who made it.

The Canadian case of St. Catherine's Milling and Lumber Co. v. The Queen elaborated on the statements of Chief Justice Marshall, and the dicta of Mr. Justice Strong in the Supreme Court of Canada offer the most complete statement on the content of aboriginal rights in Canada: ${ }^{28}$

It may be summarily stated as consisting in the recognition by the Crown of a usufructuary title in the Indians to all unsurrendered lands. This title, though not perhaps susceptible of any exact legal definition in exact legal terms was one which nevertheless sufficed to protect the Indians in the absolute use and enjoyment of their lands, while at the same time they were incapacitated from making any valid alienation otherwise than to the Crown itself, in whom the ultimate title was considered as vested.

In the Privy Council the right was further defined as being "dependent on the good will of the Sovereign." 29

Apart from these general observations, there is almost no judicial opinion in Canada as to the content of aboriginal title. We know generally that it is a communal possessory right subject to two limitations: (1) the inability to alienate except to the Crown, and (2) the vulnerability of the right to extinction by the Crown.

What, then, is the proper remedy for extinguishment of the right? Is it a mere moral fetter on Crown title or does it confer a true compensable proprietary interest on those people possessed of it? Experience in other jurisdictions is varied. American practice leans towards the view that the right is legally compensable. However, the tendency to characterize it as such is clouded by the availability of other measures on which compensation could be based which are unavailable in Canada. These include the Fifth Amendment and various Compensation Acts. ${ }^{80}$ In Australia the right has been viewed as a moral claim only, based on a benevolent policy by the Sovereign.. ${ }^{31}$ This proposition is based on the view that the historical use of the lands by the natives does not meet the

${ }^{25}$ Johnson v. McIntosh (1823) 21 U.S. (8 Wheat.) 240; Worcester v. Georgia (1832) 31 U.S. (6 Pet.) 350.

${ }^{20}$ Lester and Parker, Land Rights: The Australian Aborigines Have Lost a Legal Battle, But . . (1973) 11 Alta.L.Rev. 189 at 196-197.

27 Johnson v. McIntosh, supra, n. 25 at 254.

28 (1887) 13 S.C.R. 577 at 608 (S.C.C.).

29 (1889) 14 A.C. 46 at 54 (P.C.).

30 United States v. Alcea Band of Tillamooks (No. 1) (1946) 329 U.S. 40; United States v. Alcea Band of Tillamooks (No. 2) (1954) 341 U.S. 48; Tee-Hit-Ton Indians v. United States (1955) 348 U.S. 272.

91 Milirrpum v. Nabalco Pty. Ltd. (1971) 17 F.L.R. 141 (N.T.S.C.). 
tests of being a proprietary interest under the British common law of real property. ${ }^{32}$

The availability of these differing characterizations of the right will have important consequences in regard to any future claim for compensation in Canada where there is neither settled case law on the subject nor established statutory means of bestowing compensation. ${ }^{33}$

The general practice in expropriation cases is that compensation is given and that any statute providing for expropriation without compensation must be expressed in clear terms. Professor Cumming points out that Canadian courts have recognized the applicability of the presumption against expropriation without compensation to the owners of many forms of interest in property and even quotes dicta from one case applying the rule to a usufruct. ${ }^{34}$ The Calder case dealt indirectly with the matter and two different points of view emerged. Mr. Justice Judson interpreted recent American cases as being authority for the proposition that the obligation to pay must be based on statute ${ }^{35}$ and indicates that the right is not a compensable property right but a right of occupancy only. Mr. Justice Hall, on the other hand, intimates that any expropriation by the Crown should require compensation. ${ }^{38}$ He makes reference to the case of Oyekan v. Adele, where Lord Denning stated: ${ }^{37}$

... the courts will declare the inhabitants entitled to compensation according to their interests, even though those interests are of a kind unknown to English law.

There is ample authority for both sides of this issue and it is submitted that future government policy will likely turn on whether the courts characterize past dealings with the Indians as being benevolence on the part of the Crown or as elevating a unique system of tenure to inclusion as a property right under the common law of real property. It must be remembered that even if the latter characterization is given, the government still has the power to legislate any native claim out of existence since the right to compensation is a presumption only and subject to the supremacy of Parliament. However, a strong assertion of sufficient proprietary status in native possession by the courts would render such a government policy politically unsound. It would be tantamount to denying compensation for expropriation of a property right to native people whereas it is standard practice to award such compensation to all other Canadians. On the other hand, if the courts were to hold that past recognition of native title was benevolence only, based on practicalities and expedience in the context of government policies and native needs at that time, the government would have justification for denying compensation. There would be no property right against which the presumption could operate. As discussed below, the Caveat case creates a situation where this issue begs to be settled.

\section{Extinguishment of Title}

Since aboriginal title is "dependent on the good will of the sovereign", any consideration of the existence of such rights will involve a careful consideration of whether or not such right has been extinguished. The Calder case manifests

32 Supra, n. 26; the authors strongly criticize this view as not recognizing that previous cases had protected the property rights of natives as British subjects, whose notions of property were not comparable to the British system, by according their system of tenure a proprietary status.

88 The Indian Claims Commission in Canada does not have jurisdiction to hear claims based on aboriginal title.

ss Cumming and Mickenberg, supra; n. 14 at 45-47; Commissaires d'Ecoles v. Charbonneau [1953] Que.S.C. 477.

85 Calder et al. v. A.G. B.C., supra, n. 12 at 22-23.

86 Id. at 51.

87 (1957) 2 All E.R. 785 at 788. 
two lines of reasoning as to what sort of action is necessary by the Crown to extinguish the right. The Supreme Court of Canada reached a 3-3 deadlock on this issue and, therefore, both lines of argument are still open at law.

Mr. Justice Judson, speaking for one side of the court, held that extinguishment could be achieved by implication. This is constituted by showing that the Crown has dealt with the land in a manner inconsistent with the existence of aboriginal title. He cites such actions as "alienations in fee simple . . . by way of P.N.G. leases, mineral claims and tree farm leases". ${ }^{38} \mathrm{Mr}$. Justice Hall, on the other hand, says that the right can only be extinguished by surrender to the Crown or by express legislative authority. ${ }^{39}$ In the Northwest Territories, support can be found from both points of view to show that extinguishment has taken place.

Possible sources of dealing with the land so as to cause extinguishment by implication can be found through the use of such enactments as the Commissioner's Land Ordinance, ${ }^{40}$ giving the Commissioner a power of disposal over lands not required for public use, the Forestry Development and Research Act ${ }^{41}$ authorizing the removal of occupants from experimental forestry areas and the National Parks Act ${ }^{42}$ which authorizes the Minister to purchase or expropriate lands, including those belonging to Indians, for the purposes of a park. It is thus possible to argue, on the basis of Mr. Justice Judson's reasoning, that aboriginal title no longer exists in those areas over which the powers under these Statutes have been exercised.

If Treaties 8 and 11 are binding, then direct extinguishment has taken place since they deal directly with the cession of native lands. The only matter to be settled, in this event, is finding a satisfactory method of satisfying outstanding claims under the existing treaties. This would preclude the desire of the Indians to acquire a participating share in the future development of the North.

\section{THE CAVEAT CASE: "THE POSSIBILITY OF A CLAIM"}

It is submitted that the nature of the action resulting from the attempted filing of the caveat by the Indians, through the reference to the Territorial Court, was intended to establish a framework from which their legal claim could be more effectively established in the future while, at the same time, giving them an optimal position for negotiation. Their claim of a caveatable "interest" was based on the assumptions that the concept of aboriginal title has been recognized both by statute and common law in the Northwest Territories and that the present inhabitants fulfill the necessary prerequisites of being possessed of it. If a "prima facie" right was then found to be in existence, the stage would be set for the following legal issues to be squarely faced by the courts in any subsequent action on notice to lapse a resulting caveat:

(1) The question would arise as to whether the right has been expressly extinguished in unpatented land through Treaties 8 and 11 or by implication through existing legislation in relation to land in the N.W.T. in deciding whether a caveat could be lodged and sustained.

(2) A more precise definition would have to be given to the legal content of aboriginal title in determining whether the interest inherent in the title was sufficient to sustain a caveat.

38 Calder et al. v. A.G. B.C., supra, n. 12 at 18.

39 Id. at 51.

101969 (2nd Sess.), c. 6.

41 R.S.C. 1970 , c. F-30.

42 R.S.C. 1970 , c. N-13. 
(3) If such a right still exists in the lands in question, and is of such a nature that it is capable of protection under the Land Titles Act, when such a right becomes incompatible with future development in the North, what would be the proper method of compensation for its extinction?

At the beginning of the judgment, Mr. Justice Morrow states: ${ }^{43}$

Because of the nature of these proceedings I do not consider it necessary to consider the evidence in depth. As I see my function I am to look for a prima facie situation or a situation which may promise a possibility of a claim. At such a point, if reached, I must then stop.

By construing his function so strictly, Morrow J. has fashioned the framework for possible future consideration of a higher court. Such consideration could arise either through appeal of his decision to allow the caveat to be filed or through action on notice to lapse a resulting caveat. These actions would involve a more detailed analysis of the legal issues involved.

\section{Existence, Recognition and Obligation: The Prima Facie Interest}

The first step Morrow $\mathrm{J}$. took in finding a caveatable interest was to determine use and occupation from "time immemorial" and some form of recognition of rights arising out of this use. This is important since previous cases have not dealt specifically with either the basis or recognition of the right in the Northwest Territories and it had only been considered in passing dicta. ${ }^{44}$

The Athapascan tribes of the Mackenzie Basin were the least politically and socially developed of all the native groups in Canada. They were divided into tribal groupings but had no formal tribal organizations. Because of the harshness of their environment, they were forced to move with the food supply and were largely semi-nomadic, each tribal grouping being composed of numerous, independent bands. However, among these people there was a clear recognition of defined territories over which they hunted and they protected these territories fiercely. Therefore, their use of the land for hunting and fishing was the basis of their concept of native title. There was some question before the court as to whether this primitive use was sufficient to support a claim of aboriginal title over a defined territory. ${ }^{45}$

In the Calder case, Mr. Justice Hall stated that aboriginal title is a matter of fact and specifically recognized the need to judge possession by native concepts. ${ }^{46}$ On this basis, extensive archaeological and historical evidence, as well as first hand testimony from Indian people concerning their traditional way of life, was presented to the court. Morrow J. concluded that the people who signed the caveat were the present day descendants of those tribes who traditionally used the land and that the indicia of use, necessary to found a claim of aboriginal title, were present. He cites evidence proving the occupation of the land from primitive times by distinct groups of the ancestors of the present caveators. These people had used the land in a consistent manner for centuries and such use met the courts' standard of aboriginal title.

Morrow J, then went on to consolidate legislative authorities recognizing the right and held:

(1) The Royal Proclamation of 1763 does apply to the Northwest Territories. On the basis of the historical evidence before him, presumably

13 Caveat case, supra, n. 1 at 119.

14 E.g., R. v. Sikyea, supra, n. 24.

15 For a more detailed analysis of these people, see Hodge, Handbook of Indians of Canada (1912); Diand, Indians of the Yukon and N.W.T. (1966).

16 Supra, n. 12 at 25. 
concerning the activities of the Hudson Bay Company traders in the late eighteenth century, he concludes that the area in question was not terra incognita at the time of the passing of the Proclamation. Thus, the policy of negotiating settlement of Indian land claims is applicable to the Northwest Territories.

(2) The Order in Council of 1870, transferring the Northwest Territories and Rupert's Land to Canada provided that: ${ }^{17}$

Upon the transferance of the territories in question . . . the claim of the Indian tribes to compensation for lands required for purposes of settlement will be considered and settled in accordance with the equitable principles which have uniformly governed the British Crown in its dealings with the aborigines.

Morrow J. held that, by virtue of s. 146 of the B.N.A. Act which authorized the transfer, the Order became part of the Canadian Constitution. The above provision may thus give the Indians in the North a constitutional guarantee not possessed by other Indians in Canada.

(3) The judgment takes note of a protection in the Dominion Lands Act of $1872^{48}$ which provided that territory in which Indian title had not been extinguished was excluded from its scope.

(4) The negotiations of Treaties 8 and 11 were clearly based on the concept of aboriginal title.

\section{Mr. Justice Morrow concludes: ${ }^{40}$}

Unless, therefore, the negotiation of Treaty 8 and 11 , legally terminated or extinguished the Indian land rights, or aboriginal rights, it would appear that there was a clear constitutional obligation to protect the legal rights of the indigenous people in the area covered by the proposed caveat; and a clear recognition of such rights.

Morrow J.'s judgment, therefore, constitutes a direct finding that the natives possessed aboriginal rights which were recognized by the laws of the jurisdiction, and which were effective subject to possible extinguishment. Thus, such recognition only applies to those claims which have not been effectively settled. Such existing claims must also be found to be of a legal nature capable of manifesting adequate compensation. These are the hurdles the court had to face in finding the existence of a prima facie right.

\section{The First Hurdle-Treaties 8 and 11}

At first glance it would appear that the presence of the treaties would create an insurmountable hurdle to native assertions as constituting an express extinguishment of aboriginal title. However, the court undertook extensive and valuable research into conditions surrounding the signing of the treaties. Morrow J. observed: ${ }^{30}$

Throughout the hearings before me there was a common thread in the testimony-that the Indians were repeatedly assured they were not to be deprived of their hunting, fishing and trapping rights. To me, hearing the witnesses at first hand as I did, many of whom were there at the signing, some of them having been directly involved in the

17 Supra, n. 19 at 263.

435 Vict., c. 23, s. 42: "None of the provisions of this Act respecting the settlement of agricultural lands, or the lease of timber lands, or the purchase and sale of mineral lands shall be held to apply to territory, the Indian title to which shall not at the time have been extinguished.

19 Caveat case, supra, n. 1 at 138.

$60 \mathrm{Id}$. at 141. In the judgment Mr. Justice Morrow refers to such factors as the ultimatum atmosphere surrounding the signings, the designation of one person as chief to sign for the others when such a concept was not part of the culture, and the similarity of the X's on the documents which suggested that the formality of each person signing on his own behalf was not even complied with. 
treaty making, it is almost umbelievable that the government party could have ever returned from their efforts with any impression but that they had given an assurance in perpetuity to the Indians in the territories that their traditional use of the lands was not affected.

This finding must be contrasted with the logical conclusion to be drawn from the wording of the preambles of both treaties: "the said Indians do hereby cede, release, surrender and yield up all their rights, titles and privileges". Such comprehensive language leaves little, if anything, to survive the terms of the treaties. To rationalize these seemingly contrary situations, Morrow J. arrives at two possible conclusions from which he found sufficient probability that title had survived the treaties, at least to the extent of constituting prima facie title to support the filing of a caveat. These are:

(1) The treaties really constituted a government confirmation of its paramount title. Assurances to the natives that their rights to hunt, trap or fish were not to be taken away were in effect a form of declaration of continuing aboriginal rights in the Indians.

(2) There was no consensus ad idem in the signing of the treaties, or alternatively, the Indians thought they were signing "peace" treaties rather than giving up their rights in the land.

In these findings, Morrow J. has taken the Indians past the point where they could only press for a settlement based on the terms of the treaties. The possibility that the treaties are defective has been raised. In any subsequent action on appeal or notice to lapse the caveat a much more intensive inquiry into the status and effect of Indian treaties in law will have to be undertaken to determine the relevance of Morrow J.'s findings. There is little settled law in this area in Canada, ${ }^{\text {s1 }}$ and an extensive consideration of the possible ramifications of treaties as a result of the Caveat case could open the door for other native groups under treaty in Canada to assert further claims.

\section{The Second Hurdle: Extinguishment by Implication}

Mr. Justice Morrow did not consider the possibility that aboriginal claims had been extinguished impliedly through existing legislation. Extinguishment, by implication, requires that legislation exists which permits the land to be dealt with in a manner inconsistent with continuing native title. Judson $\mathrm{J}$. in the Calder case supported this argument but, as outlined above, Hall J. held that express legislation was necessary to extinguish aboriginal title. ${ }^{52}$ Thus, the question has been left open and the failure to consider this point is not fatal to the findings of the court. The finding of the prima facie existence of title can still stand. However, it is surprising that this undecided issue in the law of aboriginal rights was not commented upon.

It should be noted here that the Indians have, in the terms of their proposed caveat, recognized that extinguishment could take place by implication under the Land Titles Act. The caveat did not purport to cover lands already brought within the system and thus recognition was given to the fact that the indefeasibility provisions of the Act prevail over aboriginal title. The purpose, of course, of the caveat was to make future indefeasibility conditional on aboriginal rights.

\section{The Third Hurdle: A Caveatable Interest in Land}

Having found existence, legislative recognition and the possibility of the

51 For a general overview of the problems in this area see Cumming and Mickenberg, supra, $n$. 14 at 53-62. They submit three possible legal characterizations of Indian treaties from which their effect can be considered. They are: personal contracts, international treaty and legislation.

62 Supra, n. 12. 
continued existence of aboriginal rights, Mr. Justice Morrow was then required to find that such rights were capable of being the subject of a caveat under the Land Titles Act. This involved a consideration of the legal nature of the rights.

Under s. 132 of the Land Titles Act, any person claiming to be interested in any land under certain instruments listed therein, "or otherwise", may lodge a caveat with the Registrar. Morrow J. held that this language was broad enough to include aboriginal rights. He relied on the St. Catherines Milling and Calder cases as authority for holding that such rights constituted a proprietary interest in land. There is a possibility of a claim on the basis of these decisions and in this respect Morrow J. was acting within his function. However, it is submitted that his conclusion was arrived at rather summarily.

The previous cases have not explored the issue extensively enough to justify a conclusive finding that aboriginal rights constitute an interest in land. For example, the St. Catherines Milling case makes reference to a usufructuary possessory right but, apart from this general definition, no definitive statement on the legal content of aboriginal rights is given. ${ }^{.3}$ Since it is possible to distinguish the relevant American cases on the subject as being based on the Fifth Amendment and various Compensation Acts, ${ }^{54}$ it is submitted that there is a good possibility that future decisions in Canada will follow the Australian precedent. This would characterize the recognition of Indian Title as being merely a reflection of benevolence by the Crown in their dealings with native people rather than a manifestation of a proprietary interest in land. As outlined earlier, such a determination would have a great influence on the question of awarding compensation.

It is regrettable that the court, in the Caveat case, did not define this issue more clearly in setting the stage for possible future consideration of this most ambiguous area of the law of aboriginal rights.

\section{The Compromise: Political Settlement}

The Caveat case has, from a legal standpoint, set the stage for serious judicial consideration of the poorly defined area of aboriginal rights by preserving the intended framework set out earlier. On an appeal from the decision to allow the caveat to be filed, or on notice to lapse a resulting caveat if such an appeal is unsuccessful, serious consideration would have to be given to the many ramifications of this judgment. This involves the need to determine the status of the treaties and then place a working definition on the content of any surviving rights, so as to determine the legal nature and possible means of compensation flowing from them. In the face of the reluctance of previous courts to go any further than absolutely necessary in making such decisions and in view of the legal technicalities to be overcome, this becomes a formidable task and a time consuming one. Future court actions could leave the rights of both parties up in the air for a considerable period of time and lead to uncertainty in the future course of development in the North. By advancing the dispute to this stage the Caveat case serves a second function. It leads to the alternative method of manifesting aboriginal rights through negotiated settlement in lieu of further judicial proceedings. Although the judgment, at the time of writing, has been appealed by the Crown, the fact that a negotiator has also been appointed by the federal government indicates that a settlement could be reached before a final appeal decision is handed down.

Several factors over the last few years point to the reaching of such a 
settlement.55 The rejection of the assimilation-oriented White Paper of 1969,56 the Alaskan Settlement of $1972,{ }^{57}$ the trend towards some sort of legally recognized right in native people as enunciated in Calder which requires moral if not legal compensation for its extinguishment, and now, the prima facie finding of such a right in the Indians of the Northwest Territories through the Caveat case. It would appear to be beyond political prudence to overlook the existence of this course of events and deny compensation. The court cases, in particular, are showing that if there is not a legal claim there is certainly a moral one and this will not escape the public eye.

The Alaska Settlement stands as an example of the means through which such compensation could be manifested. ${ }^{58}$ The 1972 settlement provided a 500 million dollar cash payment and $2 \%$ royalty on all mineral rights ceded and the setting aside of 40 million acres of land for native use. The natives have a large degree of control over the administration of the scheme through provision for the creation of regional and village corporations. Each eligible native is entitled to membership in both the corporation established for his village and for the region in which it is located. As shareholders, they are entitled to a voice in management and a share in the lands, assets and income which are owned and managed by the corporations. The effects of the scheme will hopefully be, that with money and land available, capital improvements such as housing, transportation and service industries will be spurred. This will lead to increased meaningful employment opportunities and, hopefully, increased economic status will lead to higher education levels and increased native political strength.

In Canada there has been a trend towards acceptance of such a scheme for native administration. In the spring of 1973 , it was disclosed that the federal government had commissioned a study on a proposed Indian Trust Fund. This would transfer the federal Indian budget to the natives and divest the government of much of the jurisdiction it now holds as trustee of the native people.50 In September of 1973, the press rumored that one of the documents, stolen from the Indian Affairs Department during a militant sit-in, outlined a huge cash and land settlement for the N.W.T. Such schemes, if they became a reality, will certainly have inherent administrative difficulties but they do constitute a trend towards an enlightened approach in the handling of native affairs. It is to be hoped that both sides, negotiating such a settlement, will work towards an equitable solution in line with native needs and practical development of the resources of the region.

\section{CONCLUSION}

The native people of the Northwest Territories occupy a unique position in relation to their southern counterparts. The land affords them the physical opportunity of preserving much of their traditional culture. Government policy, in the handling of their affairs, has placed an emphasis on such factors as education, housing and medical facilities which will help them avoid many of the problems experienced through the neglect of other Canadian native people. Collectively, they comprise $65 \%$ of the northern population ${ }^{61}$ whereas the national

35 An advantage of such a settlement over court action would be that it could extend to the Eskimos as well. The Eskimos were not parties to the caveat application.

so Supra, n. 13.

5785 Stat. 688, Public Law 92-203.

58 The following summary is based on: French, Alaska Native Claims Settlement Act (1972).

59 Edmonton Journal, February 13, 1973.

60 Edmonton Journal, September, 1973.

61 Edmonton Journal, February 8, 1973. This figure includes 7,000 Indians, 5,000 Metis, and 15,000 Eskimos out of a total population of 36,000 . 
native population comprises $2.5 \%$ of Canada as a whole. All these factors contribute to their continuing existence as a separate entity. The problem is to assist them in asserting this identity in the years to come. The danger lies in their reaction to the problems of social adjustment to the white man's ways. As was pointed out in a regional economic report to the federal government: ${ }^{62}$

The transition from a trapping economy to a wage economy has begun but now lies virtually arrested at mid-stream.

A political or legal settlement arising out of the Caveat case could afford the opportunity to accomplish needed social change in the North, through active native participation in future development, and thus be a means of providing new policies for the handling of native affairs.

-RONALD H. PEARSON ${ }^{\circ}$

62 Usher, Economic Basis and Resource Use of the Coppermine-Holman Region (1965).

- B.A., member of the graduating class. 